Historic, Archive Document

Do not assume content reflects current scientific knowledge, policies, or practices. 


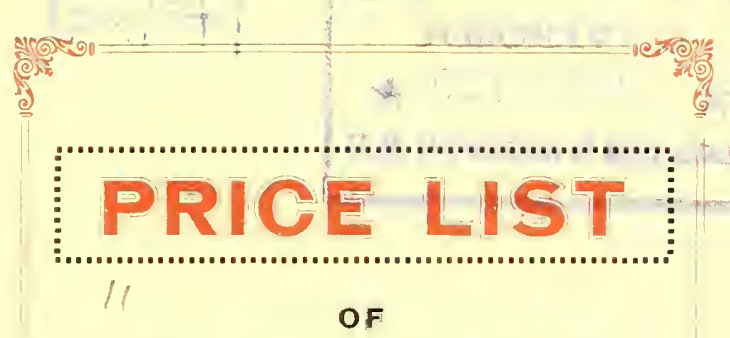

GLADIOLUS

BULBS AND BULBLETS

F A L L SPRING

$1928 \quad 1929$

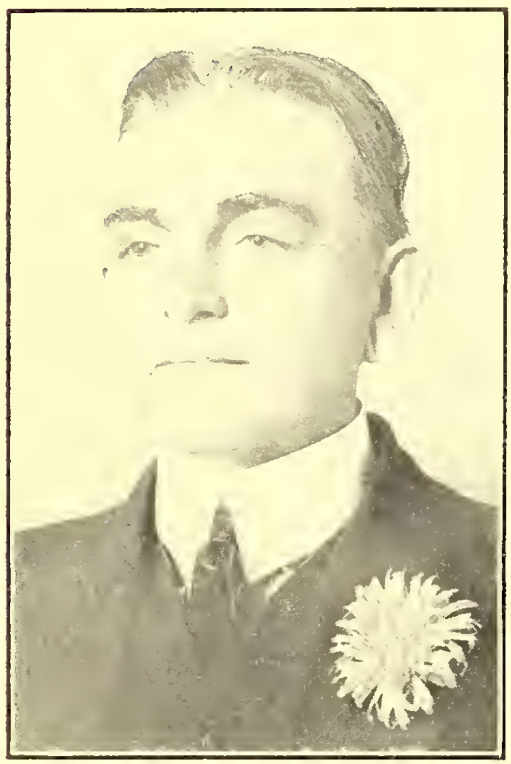

This is Me -- E. D.

@

\section{Rockland Heights} 1) Bulb Farms

\section{ALLEN - MICHIGAN}

Prices Subject to Chantye Without Notice By the Owner

ERWIN D. CARY 


\section{TIELLO FRTENDS! \\ जत}

7 ERE we are again after months of hustling with the Glads from the

J 1 preparatory stages of planting. such as fitting the soil and sorting and treating the bulbs for our 25 acres of Glads with all our help going, strong as well as ourselves, and we finally got them planted. Oh, yes. we were tired, but no time to weaken for up came millions of weeds, so we fellows just had to step right out and go after them; had the tractor humming, with hoeing and raking, etc, and just about got thru in time to go to Toledo to the National A. G. S. Show. We got there O. K. and the sight was splendid; Glads everywhere and the best ever, but no better than our own-more kinds-but you know we cannot have them all, couldn't take care of them. Yes, we shook hands with Glad Bill, and also J. D. Long of Colorado and many others, also had a splendid visit with Roscoe Huff, Secretary of A. G. S. from Goshen, Indiana. Both talked at once, don't know which stopped first, anyway we had a splendid time.

Well, we came home more enthused than ever, so looked our fields over and concluded we would take an exhibit to the State Show at Lansing, Michigan, sponsored by the officers of the Michigan Gladiolus Society at East Lansing and let them see what we are doing down here at $\mathbf{A} l l=n$, Michigan. Oh, yes, we almost forgot to tell you where. Allen is. Well, it is right in the center of the Earth, situated on the great Detroit and Chicago Road. U. S. 112, with about 10,000 cars passing daily; about 100 miles west of Detroit. Fine, isn't it? Drive slow, please, when you cone this way or you may not see it all. We wanted to show them we grew Giads down here, so my neighbor grower took his display and we took ours ind we brought home the bacon.

Was the M. G. S. a success? I will say it was a howling success--simply wonderful, indeed, with its spacious room: the great Armory was a blazing riot of colors-everything imaginahle so we came home happy to know we were among the best ever. So Glad we had Glads and good ones, too, and hetter still, Glad friends everywhert. So now we turn to our Suggestions and our List and know it will interest you when you read it over. 


\section{WHY PEOPLE WANT GLADS}

Simply because of the wide range of colors, the tall slender spikes, and the flowers last much longer than other flowers, so it is up to us growers to keep pace with the times and have on hand the best always as well as the older types that are good to meet the trade who depend on us for the best once and always. Of course we are just human beings subject to mistakes, but a good man will make such errors good.

\section{WE GROW OUR OWN BULBS}

We try to keep them pure and healthy and will meet any reliable firm on prices, quality considered.

\section{WHEN WE RECEIVE YOUR ORDER}

the first thing we do is to check up and see if we think we can fill same; if so, we acknowledge at once; if not, we return your money. Because of the early demand for Fall delivered bulbs it is impossible for us to clean, grade, count and invoice our bulbs before we start to sell.

\section{HOW WE SHIP YOUR ORDER}

On small orders, while weather permits, in not further than the third zone, we send by Parcels Post if wanted, but in cold weather we prefer express shipments for they are insured against cold. All large orders shipped by express. We pack these by first placing the bulbs in burlap bags sewed up, and packed in boxes or barrels thickly lined with paper which keeps them warm. Sent Charges Collect unless otherwise arranged. Freight shipments are sent at buyers' risk only. We pack free.

\section{FALL BUYERS ATTENTION}

For Southern Growers and greenhouse forcing we insist that we get your orders as early as possible so we may get them properly cured for the work. We surely will do our very best for you.

\section{OUR LIST AT YOUR COMMAND}

We have placed herein our Wholesale List, carefully compiled, and at very close prices. However, we allow $5 \%$ discount for Cash with Order in full, for Fall delivery.

\section{WE DO NOT GUARANTEE BULBS TO GROW OR BLOOM}

as that rests with the grower who plants for those things. We have no control of the bulbs after they leave here. Do not plant in shade and expect success as they will not flower well; they nzed the beautiful sunshine to bring them out. With these few remarks we close, hoping to meet you all some day and shake hands for we are of a great family reaching to all corners of the earth. May we have a trial? We Thank you.

THE ROCKLAND HEIGHTS BULB FARMS

Allen, Michigan

Member of A. G. S. and M. G. S.

ERWIN D. CARY, Prop. 


\section{ROCKLAND HEIGHTS BULB FARMS \\ ERWIN D. CARY \\ ALLEN, MIQHIGAN}

\section{WHOLESALE LIST - FALL 1928}

This list is made subject to change without notice, and for digging time only, as we cannot supply bulbs at these prices after winter storing. However, we will accept orders for Spring delivery on payment of $25 \%$ cf order, sold by thousand, 100 at thousand rate, F. O. B. Allen, Michigan. Thank you.

\begin{tabular}{|c|c|c|c|c|c|c|c|c|c|c|}
\hline Variety & No. 1 & No. 2 & No. 3 & No. 4 & No. 5 & No. 6 & \multicolumn{4}{|c|}{ BULBLETS } \\
\hline & & & & & & & 1,000 & Quart & Peck & Bushel \\
\hline Alice Tiplady & $\$ 16.00$ & $\$ 12.00$ & $\$ 9.00$ & $\$ 6.00$ & $\$ 4.00$ & $\$ 2.50$ & & $\$ .40$ & 5.00 & $\$ 15.00$ \\
\hline Anna Eberius & 20.00 & 15.00 & 12.00 & 8.00 & 6.00 & 3.00 & .30 & 1.00 & 8.00 & 25.00 \\
\hline Mrs. H. E. Bothin & 22.50 & 18.00 & 14.00 & 10.00 & 7.00 & 3.50 & .50 & 1.50 & 10.00 & 35.00 \\
\hline Boynton Capt & & & 25.00 & 18.00 & 12.00 & 9.00 & 2.00 & 8.00 & & \\
\hline Coleman Joe & 20.00 & 16.00 & 12.00 & 8.00 & & & & .80 & 6.00 & 20.00 \\
\hline Crimson Glow & 20.00 & 16.00 & 12.50 & 8.00 & & & & & & \\
\hline Dorothy McKibbin & 25.00 & 20.00 & 15.00 & 10.00 & & & 1.00 & 1.50 & 10.00 & 35.00 \\
\hline Doc Norton & 25.00 & 20.00 & 15.00 & 10.00 & 7.00 & 4.00 & 1.00 & 1.50 & & \\
\hline Evelyn Kirtland & & 18.00 & 14.00 & 10.00 & 6.00 & 2.50 & .50 & 1.00 & 6.00 & \\
\hline E. J. Shaylor & 20.00 & 17.00 & 14.00 & 8.00 & 6.00 & 3.50 & .50 & 1.50 & 10.00 & 30.00 \\
\hline Ford Henry & & & & 10.00 & 8.00 & 5.00 & 1.00 & 3.00 & & \\
\hline Francis King & 14.00 & 12.00 & 9.00 & 6.00 & 3.50 & 2.50 & & .50 & 5.00 & 15.00 \\
\hline Golden Measure & 40.00 & 30.00 & 25.00 & & & & & & & \\
\hline Glory Kennermerland & & 12.00 & 9.00 & 6.00 & 4.00 & 2.50 & & .50 & 5.00 & 15.00 \\
\hline Giant Nymph & 40.00 & 30.00 & 25.00 & 18.00 & 12.00 & 9.00 & 1.00 & 6.00 & 30.00 & 100.00 \\
\hline Halley & 12.50 & 10.00 & 7.00 & & & & & & & 8.00 \\
\hline 1910 Rose & 14.00 & 11.00 & 9.00 & 6.00 & 4.00 & 2.50 & & .40 & 5.00 & 15.00 \\
\hline Le Marechal Foch & 12.00 & 9.00 & 7.00 & & & & & & & 5.00 \\
\hline L-Immaculee & 22.00 & 18.00 & 15.00 & & & & & & & \\
\hline Louise & 25.00 & 20.00 & 16.00 & & & & & & & \\
\hline Peters Frederick C & 35.00 & 30.00 & 25.00 & 18.00 & 14.00 & 9.00 & 2.00 & 3.00 & 18.00 & 50.00 \\
\hline Phipps W. H. & & & & & 40.00 & 30.00 & $8.01)$ & 20.00 & 125.00 & \\
\hline Pendleton Frank & 18.00 & 14.00 & 10.00 & 7.00 & 4.50 & 3.00 & .50 & .75 & 8.00 & 30.00 \\
\hline Virginia S. P. & 25.00 & 20.00 & 15.00 & 12.00 & 8.00 & 5.00 & 1.00 & 2.00 & 10.00 & 30.00 \\
\hline Rose-Ash & 25.00 & 20.00 & 15.00 & 12.00 & 8.00 & 5.00 & 1.00 & 2.00 & 10.00 & 30.00 \\
\hline War & 22.50 & 18.00 & 15.00 & & & & 1.00 & 1.00 & 7.00 & 25.00 \\
\hline Wilbrinck & 14.00 & 10.00 & 8.00 & & & 2.00 & & & 5.00 & 15.00 \\
\hline Tyco Zang: (per 100 & & 15.00 & 12.00 & 9.00 & 7.00 & 4.00 & 3.00 & 12.00 & 75.00 & \\
\hline Gold Eagle (Each) & 1.00 & .75 & & & & & blate & $5 \mathrm{c}$ Fiact & $-\$ 150.00$ & er 1,000 \\
\hline
\end{tabular}

How Many? Terms cash with order unless otherwise arranged, shipped in December or before (when cured) fine stock guaranteed, $98 \%$ or better pure. In case of dissatisfaction will replace stock untrue, same kind and size only. Will pay no damages. You buy on these conditions only of us. 